\title{
Damaske, S. (2021) The Tolls of Uncertainty: How Privilege and the Guilt Gap Shape Unemployment in America. Princeton University Press.
}

\section{Review by Robert D. Francis}

To begin her book, The Tolls of Uncertainty, sociologist Sarah Damaske invokes the famous Depression-era portraits of the unemployed by Dorothea Lange. For Damaske, like Lange a hundred years ago, the goal is 'to see the unemployed and take up her [Lange's] call to action' (p. xi). Through interviews with one hundred unemployed workers, including many in the working class, Damaske undoubtedly accomplishes the first goal. Whether she accomplishes the second will be in the eye of the reader.

The theme of the book emerges early: 'the tolls of unemployment are both more numerous than we previously imagined and not evenly shared by the unemployed' (p. 4). The book is based upon interviews with 51 men and 49 women between 2013 and 2015 who had lost a full-time job and received unemployment from the state of Pennsylvania. Just over half of the cases were working class, defined in this research as those who held jobs that did not require a college degree. The predominant whiteness of the sample is reflective of the field site but makes conclusions about race more difficult to draw from these cases alone.

The book is divided into three sections that follow the experience of unemployment: Part I: Losing A Job; Part II: The Fallout; and Part III: The Search. Although Damaske and her team interviewed 100 people, she focuses on the stories of four people to provide a narrative thread throughout the book: Tracy, a working-class woman; Neil, a middle-class man; Joan, a middle-class woman; and Anthony, a working-class man. We meet others along the way as Damaske unfolds the experience of job loss.

Damaske does not focus exclusively on working-class people, but the fact that her data tell stories of unemployment across social classes is a strength of the book. Having male and female subjects in both working-class and middle-class jobs allow for fruitful comparisons. It is no surprise that working-class people sometimes react differently to job loss than their middle-class counterparts. For example, Damaske writes that job loss is so common among her working-class male respondents that many of them displayed less anxiety when they lost work compared with those in the middle class, despite the fact that the working-class men were in more unfavorable economic circumstances.

For many readers, Damaske's topline findings will not be surprising: unemployment 'generates and reproduces inequalities between the employed and the unemployed, but also among the unemployed' (p. 9). White respondents on average fare better than respondents of color; men fare 
better than women; and those from the middle class fare better than those from the working class. As she writes, 'people from groups that have historically been marginalized-white women, the working class, and people of color — are the ones whom we have left behind' (p. 34).

While Damaske's headlines might be unsurprising, the real success of the book is in the stories of unemployed people. Each chapter is written with empathy and rigor as Damaske seamlessly weaves the stories of her respondents with existing academic literature about unemployment. Her writing is accessible and avoids jargon, making the book available for a wide audience. She points out when her findings support existing work, as well as when her findings seem to break new ground. For those in classrooms, the book is ripe for use with students.

Damaske's central finding, around which she builds two of her eight chapters, is what she calls the 'guilt gap,' by which she means the fact that women in her study exhibit more guilt about their unemployment than men. The guilt gap affects both health and household. While previous research finds that women have healthier habits than men, the guilt woman feel about their unemployment lead women in the study to defer health insurance and health care in favor of kids and partners. Men show no such deference where their own health is concerned. Damaske also finds that women in the study bear the lion's share of the household duties when unemployment hits, even in cases where couples tried to share duties equitably during employment. Unemployed middle-class men - often buoyed by savings, severance, and high-earning spouses - see unemployment almost as a vacation from domestic duties. Working-class men are more likely than middle-class men to look for work right away, but they too are not likely to step up at home when out of work, even if their partner is still working.

I found myself particularly interested in Damaske's observations about the labor market pathways of her subjects. By using a life course approach, Damaske has each person's full employment (and unemployment) history, allowing her to document what led to the job loss. She finds three distinct labor market paths: lockstep, in which respondents had job stability, few employers, and rare job loss; chronic unemployment, in which 'losing a job was just another part of having a job' (p. 41); and transitory, which is between the other two. Resonant with my own work among working-class men, she finds that workers stick with jobs that stick with them. But page after page of the book is filled with testimonies of the many ways in which workers were cast aside. While tales of full plant or company closures are virtually absent from these stories (a notable difference from the workingclass literature of the 1980s and 1990s), there is a new normal of 'small batch' firings that can almost be described as casual. I think of Damaske's story of Alana, the top salesperson at a local business for sixty straight months, who was unceremoniously fired within a week of asking for raise.

I was also especially interested in the chapter about returning to work, in which Damaske describes the approach her respondents took after job loss. She identifies four types of job search among her respondents: Deliberate, Take Time, Urgent, and Diverted. This is another area where social class differences emerged: 'the working class appear doubly disadvantaged - both in their financial precarity and in how their insecurity constrained their [job] searches' (p. 179). These searches take place within the parameters of Pennsylvania's unemployment insurance (UI) system, which Damaske touches on in this chapter and elsewhere in the book. I think there was a missed opportunity to make the UI system, including the caseworkers, more of a central character. For 
example, in my own work among working-class men in Pennsylvania, I found a gamesmanship between unemployed men and the UI system that seems absent among Damaske's cases.

In some respects, one of the most telling findings about the working class is in the data Damaske and her team failed to gather. She and her team attempted to contact respondents about a year after the initial interviews, and they were unable to find half of the working-class men they had spoken with just a year earlier. Phone numbers out of service, emailed returned, and addresses changed. She supposes that many relocated, but their absences speak volumes about the insecurity and precarity of these men's lives. In the final chapter, 'One Year Later', Damaske and her team find the working-class men and women struggling, about equally as likely to have fallen even further behind.

Compelling as the book is, some readers might find themselves looking for more meta-analysis. Damaske is disciplined in sticking within the bounds of her data, but a polemic against capitalism this book is not. Damaske is not dispassionate, but as an academic, she leans into her interviews, leaving it to the reader to decide how to translate her findings into action. Damaske says at the book's beginning that she wants to follow Lange's footsteps into action, but I suspect that some readers might want more radical solutions than the policy suggestions she offers in the book's final few pages: clearer UI rules, more generous UI benefits, fewer job search requirements, and a societal safety net with better childcare and healthcare supports.

There is always an element of chance with the timing of any research. As Damaske notes at the outset, her research on unemployment took place in the middle of a decade of unprecedented economic growth, half a decade after The Great Recession and half a decade before the worldwide pandemic. COVID-19 had emerged when she was reviewing her final draft, so she could at least nod to recent developments in the book. She heads off critics by asking what we might learn about job loss during relatively good times, answering her own question by suggesting that if unemployment is devastating and unequally shared in times of plenty, one can only imagine the toll during bad times. We will need current work to understand employment-and unemployment - in our COVID-19 moment; however, The Tolls of Uncertainty provides us an invaluable backdrop that is a must-read for any who are concerned about unemployment - and the unemployed.

\section{Reviewer Bio}

Robert Francis is Assistant Professor of Sociology at Whitworth University in Spokane, Washington. His research interests include U.S. poverty and inequality, the working class, and rural communities. His work has appeared in RSF: The Russell Sage Foundation Journal of the Social Sciences, Socius, and the Journal of Economic Perspectives. 